Олександр Лазоренко, кандидат психологічних наук Національна академія Державної прикордонної служби України імені Богдана Хмельницького ORCID ID 0000-0001-8574-4882

\title{
ПОРІВНЯЛЬНИЙ АНАЛІЗ ОСВІТНЬО-ПРОФЕСІЙНОЇ ПРОГРАМ ПІДГОТОВКИ МАЙБУТНІХ БАКАЛАВРІВ БЕЗПЕКИ ДЕРЖАВНОГО КОРДОНУ УКРАЇНИ ТА ЄВРОПЕЙСЬКОГО СОЮЗУ
}

У статті проведено порівняльний аналіз освітньо-професійної програми підготовки майбутніх бакалаврів безпеки державного кордону з Уніфікованою програмою підготовки прикордонників Європейського Союзу. Доведено, щчо програми підготовки мають як спільні риси, так $i$ відмінні ознаки. Виявлено, щзо часткова невідповідність рекомендаціям Уніфікованої програми обумовлена особливістю національного законодавства щзодо розмежування функиій державних органів, які здійснюють діяльність на державному кордоні. На думку автора, поєднання практичного досвіду навчання прикордонників України та СС сприятиме розв'язанню багатьох проблем, що існують в системі підготовки майбутніх бакалаврів безпеки державного кордону.

Ключові слова: порівняльний аналіз; підготовка; майбутні бакалаври безпеки державного кордону; прикордонники.

Постановка проблеми. Процес входження України в європейський освітній та науковий прості, необхідність подальшої адаптації підготовки військових кадрів до «болонських» стандартів 3 урахуванням стратегічного курсу України на інтеграцію до ЄС та євроатлантичних структур спонукає шукати нові підходи до організації навчання військових фахівців, в тому числі, майбутніх бакалаврів безпеки державного кордону. Сьогодні стратегічні пріоритети розвитку Національної академії Державної прикордонної служби України імені Богдана Хмельницького (НАДПСУ) на період до 2021 року передбачають забезпечення інтеграції академії як рівноправного партнера у міжнародний науково-технічний, освітній, культурний простір та створення умов для академічної мобільності персоналу академії [1].

Вирішення цих завдань, а також удосконаленню системи навчання майбутніх бакалаврів безпеки державного кордону сприятиме науковопедагогічний аналіз зарубіжного досвіду щодо організації освіти офіцерівприкордонників у високорозвинених країнах, зокрема у Європейському Союзі. Порівняння практичного досвіду організації підготовки співробітників прикордонних відомств країн Свропейського Союзу та України допоможе встановити відповідність європейським та світовим стандартам якості підготовки майбутніх бакалаврів безпеки державного кордону. Це наблизить національну систему військової освіти до загальноєвропейської, що ї визначає актуальність статті.

Аналіз останніх досліджень і публікацій. Аналіз літературних джерел свідчить про невпинне зростання уваги науковців до удосконалення підготовки 
офіцерів-прикордонників 3 урахуванням зарубіжного досвіду підготовки фахівців. Сучасні світові тенденції підготовки прикордонників розглянуто в дослідженнях С. Білявця [2], І. Блощинського [3; 4], Ю. Сичевського [5], Н. Ринденко [6] та багатьох інших. Значний інтерес для нашого дослідження становлять наукові розробки щодо Уніфікованої програми підготовки прикордонників та галузевої рамки кваліфікацій країн ЄС [7; 8].

Проведений аналіз наукових праць свідчить, що підготовка представників прикордонної охорони є тривалий, багатоступеневий і безперервний процес, що потребує значних зусиль при засвоєнні відповідних теоретичних знань i практичних навичок. Незважаючи на значну кількість досліджень у галузі підготовки фахівців для прикордонних відомств, зіставні порівняльні дослідження практично відсутні на сучасному етапі.

Методи дослідження - науковий аналіз проблеми дослідження; узагальнення та систематизація теоретичних даних щодо підготовки прикордонників; порівняння, класифікація, індукція та дедукція.

Метою статті $є$ здійснення порівняльного аналізу структури та змісту освітньо-професійної програми підготовки майбутніх бакалаврів безпеки державного кордону (ОПП’2018) з Уніфікованою програмою підготовки прикордонників Свропейського Союзу (ССС'2017).

Виклад основного матеріалу. Найбільш значимим проектом, що має на меті стандартизацію процесу навчання прикордонників Європейського Союзу $\epsilon$ Common Core Curriculum for Border Guards Basic Training in the European Union (CCC) - Уніфікована програма базового рівня для підготовки фахівців 3 охорони кордону країн ЄС. Цей документ розроблений Європейським агентством FRONTEX (Свропейське агентство 3 охорони зовнішніх кордонів країн-членів (C) у співпраці з представниками держав-членів СС та країн, що співпрацюють з FRONTEX. Для відображення змін в обстановці на зовнішніх кордонах $\mathrm{CC}$ а також нових завдань FRONTEX, введених Європейським регламентом з охорони кордонів та берегової охорони в 2017 році, ССС була оновлена.

Порівнюючи програми підготовки прикордонників СС [9] та України [10] ми дійшли висновку, що співробітники прикордонної та берегової охорони (ПБО) країн Свросоюзу отримують грунтовну теоретичну та практичну підготовку. Для досягнення надійної охорони державного кордону в прикордонників формуються необхідні знання, навички та компетенції.

При порівнянні структур навчання прикордонників у ЄС та Україні виявлено, що на сучасному етапі в обох країнах спостерігається перехід до ступеневих моделей підготовки [8]. Таким чином, структура підготовки майбутніх офіцерів-прикордонників у $\epsilon C$ та Україні організована 3 дотриманням вимог «Болонської» декларації.

Передусім слід зазначити, що ССС'2017 не встановлює жодних точних термінів навчання. Тривалість залежить від рекомендованого терміну навчання бакалавра денної форми національного законодавства про освіту. 
У системі підготовки прикордонників ЄС спостерігається особистісноорієнтований підхід у навчанні. Його застосування дає можливість підтримувати та розвивати у студентів автономію та особисту відповідальність за їх професійний розвиток. Також, з урахуванням оперативного характеру роботи співробітників прикордонних служб, значна увага приділяється розвитку практичних навичок. У зв'язку з цим, результати навчання також відображають практичний підхід до освітнього процесу. У світлі особистісноорієнтованого та практико-орієнтованого підходів особливе значення мають активні методи навчання прикордонників СС. По-перше, це сприяє поєднанню навчання $з$ практикою, що як найкраще допомагає розвивати нові уміння та компетенції. По-друге, особистісно-орієнтований підхід у навчанні вимагає прозорості результатів навчання та методів оцінки з точки зору активної участі в освітньому процесі [9].

В українській системі навчання прикордонників переважає проблемноорієнтоване та контекстне навчання, в якому динамічно моделюється предметний та соціальний зміст професійної діяльності. Цим забезпечується умови трансформації навчальної діяльності курсанта у майбутню професійну діяльність.

Досліджуючи ССС'2017 було встановлено, що вона складається 3 Загального розділу і трьох модулів: «Повітряний кордон», «Сухопутний кордон» $\mathrm{i}$ «Морський кордон». Загальний розділ складається 3 трьох частин: загальна прикордонна підготовка, загальна правоохоронна підготовка та практичні навички. В свою чергу кожен із модулів містить частини: спеціальне законодавство (з модуля) та практична підготовка. Розділи поділені на частини, в яких визначено теми 3 переліком орієнтовного змісту занять. Всього в ССС'2017 визначено 9 базових тем та 256 занять з орієнтовним змістом.

Відповідно до провідної ідеї ССС'2017, всі прикордонники повинні вивчати Загальний розділ відповідно до національного законодавства і потреб. Якщо провести аналогію з ОПП'2018, то в НАДПСУ курсанти всіх спеціальностей на 1-му та 2-му курсі навчання вивчають єдину програму. В подальшому на 3-му та 4-му курсі навчання підготовка стає більш спеціалізованою у відповідності до галузі знань та спеціальності, з якої здійснюється підготовка. Також здійснюється відбір курсантів для навчання за додатковим професійним спрямування спеціальності «Безпека державного кордону», наприклад, оперативно-службова діяльність підрозділів прикордонної служби, оперативно-службова діяльність підрозділів прикордонного контролю тощо. Тобто, на останніх курсах навчання курсанти поглиблено вивчають дисципліни професійного спрямування, результати навчання з яких їм будуть необхідні у подальшій професійній діяльності. Такий підхід повністю відповідає ідеї ССС'2017. Тобто, якщо очікується, що прикордонники будуть працювати на сухопутній ділянці кордону i в аеропортах, додатково до Загального розділу вони повинні пройти модулі «Сухопутний кордон» $\mathrm{i}$ «овітряний кордон». 
Для більш детального порівняння змісту програм ССС'2017 з ОПП'2018, було здійснено порівняння тематики ССС'2017 3 аналогічною тематикою навчальних дисциплін ОПП'2018. Порівняльний аналіз отриманих даних дає значний обсяг аналітичного матеріалу та демонструє певні педагогічні тенденції у принципах організації освітнього процесу співробітників прикордонної охорони обох держав. В кожній із розглянутих навчальних програм важливість поєднання теоретичного матеріалу 3 практичним виконанням завдань за призначенням визнано безперечним елементом навчання, на якому базована організація усіх інших дисциплін. Такий підхід $\epsilon$ цілком закономірним, адже майбутні прикордонники вже під час навчання повинні набути максимально-можливих професійних умінь, навичок та компетенцій. Окрім цього, у досліджуваних програмах основна увага акцентується на питаннях забезпечення безпеки державного кордону в якості ключового елементу професійної підготовки прикордонників.

Порівнюючи тематику розділу «Загальна прикордонна підготовка» ССС'2017 з відповідною тематикою навчальних дисциплін ОПП'2018 (таблиця 1), яка реалізується в НАДПСУ, ми дійшли висновку, що в цілому тематика програм подібна між собою. Кожна тема Уніфікованої програми знаходить своє відображення у тамах навчальних дисциплін національної програми підготовки майбутніх бакалаврів безпеки державного кордону.

\section{Відповідність тематики «Загальна прикордонна підготовка» ССС'2017}

Таблиия 1 навчальним дисциплінам ОПП'2018

\begin{tabular}{|c|c|}
\hline Тематика СCC'2017 & Дисципліни ОПП’2018 \\
\hline 1.1. Розвиток охорони кордону & Історія України та української культури \\
\hline 1.2. Прикладна психологія & $\begin{array}{l}\text { Психологія екстремальної діяльності } \\
\text { Військова педагогіка та психологія }\end{array}$ \\
\hline $\begin{array}{l}\text { 1.3. Навички комунікації та зв'язків } 3 \\
\text { громадськістю }\end{array}$ & Основи управління \\
\hline 1.4. Полікуртурність & Соціологія та релігієзнавство \\
\hline 1.5. Професійна етика & $\begin{array}{l}\text { Етика професійної } \\
\text { прикордонника }\end{array}$ \\
\hline 1.6. Основоположні права людини & Правове забезпечення охорони кордону \\
\hline $\begin{array}{l}\text { 1.7. Навчання професійної англійської } \\
\text { мови }\end{array}$ & $\begin{array}{l}\text { Іноземна мова за професійним } \\
\text { спрямуванням }\end{array}$ \\
\hline
\end{tabular}

Так, наприклад, тема «Розвиток охорони кордону» ССС'2017 відповідає тематиці навчальної дисципліни «Історія України та української культури» ОПП’2018; «Професійна етика» відповідає програмі навчальної дисципліни «Етика професійної діяльності прикордонника», «Навчання професійної англійської мови» відповідає програмі навчальної дисципліни «Іноземна мова за професійним спрямуванням» і т.д.

Найбільш цікавим у контексті теми дослідження є порівняльні показники тематики ССС'2017, відведеної для вивчення частини 2 «Загальна правоохоронна підготовка». Щодо цієї частини, то тут теж суттєвої різниці не виявлено. Аналогічно, як прикордонники $\mathrm{CC}$, так і прикордонники України 
вивчають основи інтегрованого управління кордонами, національне законодавство 3 питань охорони державного кордону, види $\mathrm{i}$ ознаки протиправної діяльності на державному кордоні та їх характеристику, порядок адміністративного та кримінального провадження у справах порушення законодавства $з$ прикордонних питань та ін.

Для прикладу, наведемо відповідність тематики «Охорона кордону» та «Перевірка документів» ССС'2017 3 аналогічними темами навчальних дисциплін ОПП'2018, яке відображене в таблиці 2.

Таблиия 2

Відповідність тем «Охорона кордону» та «Перевірка документів» ССС'2017 з темами навчальних дисциплін ОПП'2018

\begin{tabular}{|l|l|}
\hline \multicolumn{1}{|c|}{ Тематика ССС'2017 } & \multicolumn{1}{|c|}{ Дисципліни ОПП'2018 } \\
\hline 2.6. Охорона кордону & $\begin{array}{l}\text { Тактика прикордонної служби } \\
\text { Прикордонний контроль } \\
\text { Інженерне забезпечення охорони кордону }\end{array}$ \\
\hline 2.7. Перевірка документів & $\begin{array}{l}\text { Прикордонний контроль } \\
\text { Тактика прикордонної служби }\end{array}$ \\
\hline
\end{tabular}

Результати досліджень свідчать, що у переважній більшості зміст вищевказаних тем стосуються навчальних дисциплін «Тактика прикордонної служби» та «Прикордонний контроль» i повністю відображені в програмі підготовки майбутніх бакалаврів безпеки державного кордону. Зокрема, в обох програмах достатньо уваги приділяється вивченню обстановки в районі виконання завдань, екіпіровці прикордонних нарядів, тактико-технічним характеристикам та застосуванню технічних засобів охорони кордону (тепловізорів, пристроїв нічного бачення, біноклів, безпілотних літальних апаратів тощо), а також порядку організації та несення служби різних видів прикордонних нарядів (прикордонний патруль, групи переслідування (пошуку), перевірка несення служби, засідка, контрольний пост тощо).

Аналізуючи третю частину Загального розділу «Практичні навички» ССС'2017 відмічаємо, що він конкретизований в ОПП'2018 низкою дисциплін, тематика яких є аналогічною $з$ європейською програмою (табл. 3). Тематика цього блоку підкреслює практичну спрямованість досліджуваних програм та забезпечує прикордонників необхідними компетенціями щодо застосування заходів примусу (затримання, огляд, застосування спеціальних засобів), різних видів зброї відповідно до чинного законодавства, забезпечення захисту інформації, налагодження та підтримання взаємодії 3 представниками правоохоронних відомств та підрозділів з питань охорони кордону.

За результатами аналізу третьої частину Загального розділу «Практичні навички» СCC'2017 відмічається незначна різниця у змісті занять низки тем. Наприклад, стосовно вмінь прикордонників застосовувати зброю, то в ОПП'2018 ці уміння посилюються навчальною дисципліною «Засоби посилення прикордонних підрозділів». 
Відповідність тематики «Практичні навички щодо стандартів прикордонної та берегової охорони» ССС'2017 навчальним дисциплінам ОПП'2018

\begin{tabular}{|c|c|}
\hline Тематика ССC'2017 & Навчальні дисципліни ОПП'2018 \\
\hline $\begin{array}{l}\text { 3.1. Тактичні процедури у діяльності } \\
\text { прикордонної та берегової охорони }\end{array}$ & $\begin{array}{l}\text { Тактика прикордонної служби } \\
\text { Фізичне виховання та застосування сили }\end{array}$ \\
\hline $\begin{array}{l}\text { 3.2. Інформаційні технології та комунікації, } \\
\text { безпека та захист даних }\end{array}$ & $\begin{array}{l}\text { Зв'язок в прикордонних підрозділах } \\
\text { Програмно-технічні } \\
\text { прикордонних підрозділів } \\
\text { Основи інформаційної безпеки }\end{array}$ \\
\hline 3.3. Службова вогнева підготовка & $\begin{array}{l}\text { Вогнева підготовка } \\
\text { Засоби посилення прикордонних підрозділів }\end{array}$ \\
\hline 3.4. Фізична підготовка & Фізичне виховання та застосування сили \\
\hline $\begin{array}{l}\text { 3.5. Надання першої допомоги та техніка } \\
\text { безпеки }\end{array}$ & $\begin{array}{l}\text { Безпека життя і діяльності } \\
\text { Тактична медицина }\end{array}$ \\
\hline $\begin{array}{l}\text { 3.6. Загальні положення про повітряні, } \\
\text { сухопутні та морські кордони }\end{array}$ & $\begin{array}{l}\text { Прикордонний контроль } \\
\text { Тактика прикордонної служби }\end{array}$ \\
\hline 3.7. Співпраця з іншими відомствами & $\begin{array}{l}\text { Прикордонний контроль } \\
\text { Тактика прикордонної служби }\end{array}$ \\
\hline
\end{tabular}

Так, майбутні бакалаври безпеки державного кордону навчаються застосовувати групову зброю (станкові кулемети, автоматичні гранатомети) тощо, озброєння броньованих автомобілів та бронетранспортерів, протитанкові засоби, засоби боротьби з повітряними цілями противника та ін. В першу чергу, формування таких компетентностей в українських прикордонників зумовлено необхідністю протидії збройної агресії Російської Федерації на сході нашої держави та залученням прикордонників до операції об'єднаних сил.

Також, 3 теми «Фізична підготовка» в ОПП’2018 відсутня тематика 3 плавання, що пов'язано з відсутністю необхідної матеріальної бази. Стосовно теми «Співпраця з іншими відомствами», то в ОПП’2018 вона представлена у різних дисциплінах. Зокрема, при вивченні навчальної дисципліни «Тактика прикордонної служби» розглядаються практичні питання підтримання взаємодії з підрозділами національної поліції, членами громадських формувань 3 охорони громадського порядку та державного кордону, підрозділами Національної гвардії України та Збройних Сил України тощо. При вивченні навчальної дисципліни «Прикордонний контроль» вивчається практика підтримання взаємодії з представниками контрольних служб, які здійснюють свою діяльність в пунктах пропуску (Державна фіскальна служба України, Державна екологічна інспекція України, Державна ветеринарна та фітосанітарна служба України тощо).

В цілому, набуття прикордонниками практичних навичок досить широко представлено в досліджуваних програмах. Практичні навички набуваються та удосконалюються під час різних видів практичних занять відповідно до створених умов їх застосування. Такий підхід має на меті створити навчальне середовище, наближене до реальних професійних ситуацій, і таким чином полегшити навчальний процес. 
Аналізуючи модуль «Сухопутний кордон» ССС'2017 відмічаємо, що в цілому зміст розділів модуля «Спеціальна нормативно-правова база у сфері охорони сухопутних кордонів» та «Практична підготовка 3 питань охорони сухопутного кордону» знаходить своє відображення в тематиці дисциплін ОПП'2018. Частина практичних занять 3 охорони сухопутного кордону, поділяється на заняття 3 безпосередньої охорони кордону, а частина прикордонного контролю в пунктах пропуску (автомобільних, водних i залізничних), спеціальних тактичних методів правоохоронної діяльності на сухопутному кордоні. Тематика 3 питань та пошуково-рятувальних операцій представлена в ОПП'2018 заняттям «Робота начальника відділення інспекторів прикордонної служби в умовах надзвичайних ситуацій».

Аналіз модуля «Морський кордон» ССС'2017 вказує на той факт, що майбутні бакалаври безпеки державного кордону в НАДПСУ вивчають лише особливості охорони морських кордонів. Наприклад, 3 дисципліни «Тактика прикордонної служби» передбачено вивчення тематики «Особливості охорони державного кордону у різних фізико-географічних умовах», в т.ч. на морській ділянці. При вивченні дисципліни «Прикордонний контроль» розглядається тематика щодо здійснення прикордонного контролю в морських пунктах пропуску. Натомість ССС'2017 пропонує для вивчення достатньо об'ємний модуль.

Встановлено, що декілька дисциплін з модуля «Морський кордон» в ССС 2017 не знайшла свого аналогу в ОПП 2018. Така тематика, як «Пошуковорятувальні дії на морських кордонах» та «Функції берегової охорони пов'язані 3 морськими кордонами» стосуються компетенції морської охорони, оперативнорятувальної служби цивільного захисту України, служб безпеки мореплавання судновласників і інших державних органів та служб. Зокрема, у відповідності до Закону України «Про Державну прикордонну службу України» охорону державного кордону на морі, річках, озерах та інших водоймах; контроль за плаванням і перебуванням українських та іноземних невійськових суден i військових кораблів у прилеглій зоні, територіальному морі та внутрішніх водах України та інше здійснює морська охорона. Тому, тут спостерігаються відмінності національного законодавства 3 законодавством $Є С$ щодо розмежування функцій державних органів, які здійснюють свою діяльність на державному кордоні. Це відображається у програмах підготовки відповідних фахівців.

Однак, відповідно до загальних положень ССС'2017 модуль «Морський кордон» можна включити в будь-яку національну навчальну програму як самостійний елемент, або поділити на теми, об'єднавши з відповідними темами «Загального розділу» відповідно до змісту. У цілому, майбутні бакалаври безпеки державного кордону здобувають необхідні знання, навички та компетентності, необхідні для забезпечення охорони морської ділянки. Тобто, в цілому ОПП'2018 з питань вивчення охорони морських кордонів відповідає ідеї CCC'2017. 
Аналогічна ситуація простежується в ході порівняння модуля «Повітряний кордон» ССС'2017 з програмою ОПП'2018. Спеціальна нормативно-правова база у сфері охорони повітряних кордонів вивчається курсантами НАДПСУ в обсязі, необхідному для здійснення прикордонного контролю в пунктах пропуску для повітряного сполучення під час вивчення дисциплін «Правове забезпечення охорони кордону» та «Прикордонний контроль». Також, в повному обсязі курсанти навчаються практичним діям щодо здійснення прикордонного контролю в аеропортах, впровадження аналізу ризиків на повітряному кордоні, перевірки документів на право перетину кордону. Значну увагу приділено налагодженню та підтриманню взаємодії 3 суміжними органами та службами, діяльність яких пов'язана 3 охороною державного кордону в аеропортах. Однак, питання пов'язані з забезпеченням безпеки та заходів 3 охорони кордону в аеропорту в українському законодавстві належать до компетенції Державної служби України з нагляду за забезпеченням безпеки авіації та Державної авіаційної служби України. В цьому аспекті теж виявляються особливості національного законодавства, що відображається у програмах підготовки відповідних фахівців.

Таким чином, 3 точки зору охорони кордону та основних функцій співробітників прикордонних служб на морській ділянці, сухопутній ділянці та в аеропортах ОПП’2018 відповідає рекомендаціям ССС'2017. Специфічні професійні знання, навички та компетенції, які стосуються забезпечення безпеки в аеропорту, ведення пошуково-рятувальних дій на морських кордонах та функцій берегової охорони щодо охорони морських кордонів в Україні належать до компетенції інших державних органів та служб. Однак, в НАДПСУ курсанти отримують відповідні знання щодо повноважень відповідних служб, органів та підрозділів в контексті охорони державного кордону ознайомчого характеру.

3 іншого боку, є низка дисциплін в ОПП'2018, що не мають свого аналогу в ССС'2017. 3 обов'язкових дисциплін - це «Філософія», «Політичні та економічні системи», «Основи природничих і технічних знань»; 3 дисциплін циклу професійної підготовки - це «Загальна тактика», з вибіркових дисциплін - «Спеціальна дисципліна».

Щодо вищевказаних дисциплін, то в ОПП'2018 вони відповідають вимогам Державного стандарту підготовки фахівців зі спеціальності «Безпека державного кордону». Їх впровадження в освітній процес НАДПСУ обумовлено потребами реалізації професійних компетентностей майбутніх бакалаврів безпеки державного кордону в програму їх підготовки.

Висновки. Проведений аналіз надав можливість встановити, що системи підготовки прикордонників України та СС мають як спільні риси, так і відмінні ознаки. Зокрема встановлено повну відповідність змісту Загального розділу та модуля «Сухопутний кордон» ССС'2017 тематиці ОПП'2018. Підготовка прикордонників СС та України має яскраво виражену практичну спрямованість. Часткова відповідність рекомендаціям ССС'2017 модулів «Повітряний кордон» та «Морський кордон» обумовлена особливістю національного законодавства 
щодо розмежування функцій державних органів та служб, що відображається у програмах підготовки відповідних фахівців. Крім того, враховуючи складність воєнно-політичної обстановки на сході нашої держави, в ОПП'2018 більше уваги приділено дисциплінам військово-прикордонного спрямування.

У переважній більшості дисципліни ОПП'2018 в цілому відповідають тематиці ССС'2017, що свідчить про інтеграцію системи навчання майбутніх бакалаврів безпеки державного кордону до європейського освітнього простору. Здійснений порівняльний аналіз програм професійної підготовки прикордонників СС та України дає можливість виокремити ідеї та положення, які $є$ актуальними і перспективними для впровадження підготовки майбутніх бакалаврів безпеки державного кордону. На нашу думку, поєднання практичного досвіду навчання прикордонників України та ЄС сприятиме розв'язанню багатьох проблем, що існують в системі підготовки майбутніх бакалаврів безпеки державного кордону.

Перспективи подальших досліджень. Перспективним напрямком подальших наукових розвідок, на нашу думку, є порівняння компетентностей та результатів навчання програм підготовки прикордонників ЄС та України, а також реалізація нових ідей в навчанні майбутніх бакалаврів безпеки державного кордону.

\section{ЛIТЕРАТУРА}

1. Стратегія розвитку Національної академії Державної прикордонної служби України імені Богдана Хмельницького на період до 2021 року, схвалено на засіданні вченої ради Національної академії Державної прикордонної служби України імені Богдана Хмельницького, протокол від 16 квітня 2015 року № 5. Хмельницький : Вид-во Нац. акад. Держ. прикордон. служби України ім. Б. Хмельницького, 2015. 33 с.

2. Білявець С. Я. Тенденції професійної підготовки фахівців прикордонних відомств у провідних країнах Європи в XX-XXI століттях. Молодий вчений, 2017. №7 (47). С. $257-$ 262.

3. Bloshchynskyi I. H. Peculiarities of professional training of the US Border Patrol Special Operations Group`s agents. Comparative Professional Pedagogy. 2017. Vol. 7. Issue 3. pp. $42-48$.

4. Bloshchynskyi I. H. Peculiarities of US Border Guard Officer's Training at the Federal Law Enforcement Training Center Using Online Campus. Comparative Professional Pedagogy. 2015. Vol. 5. Issue 4. pp. 57-61.

5. Сичевський Ю. О. Особливості підготовки майбутніх офіцерів митноприкордонної служби Сполучених Штатів Америки до здійснення прикордонного контролю. Збірник наукових праць Національної академії Державної прикордонної служби України. Серія : Педагогічні науки. 2017, № 4. С. 388-403.

6. Ринденко Н. М. Тенденції комунікативної підготовки курсантів навчальних закладів Прикордонної варти Республіки Польща: автореф. дис. ... канд. пед. наук: 13.00.04 / Нац. акад. Держ. прикордон. служби України ім. Богдана Хмельницького. Хмельницький, 2016. $20 \mathrm{c}$.

7. Балендр А. В. Структура галузевої рамки кваліфікацій для підготовки прикордонників країн Європейського Союзу. Військова освіта. 2017, № 1. С. 12-18. URL: http://nbuv.gov.ua/UJRN/vios_2017_1_4. 
8. Балендр А. В. Уніфікована програма базового рівня для підготовки фахівців 3 охорони кордону країн Європейського Союзу. Педагогічний дискурс. 2018, №25. С.17-21. URL: https://doi.org/10.31475/ped.dys.2018.25.02.

9. Common Core Curriculum for Border Guard Basic training in the European Union (CCC 2017). (2017). Warsaw, Poland: Rondo ONZ 1.

10. Освітньо-професійна програма першого рівня вищої освіти за спеціальністю 252 «Безпека державного кордону» галузь знань 25 «Воєнні науки, національна безпека, безпека державного кордону». Хмельницький : Вид-во Нац. акад. Держ. прикордон. служби України ім. Б. Хмельницького, 2018. 55 с.

\section{REFERENCES}

1. Stratehiya rozvytku Natsionalnoyi akademiyi Derzhavnoyi prykordonnoyi sluzhby Ukrayiny imeni Bohdana Khmelnytskoho na period do 2021 roku, skhvaleno na zasidanni vchenoyi rady Natsionalnoyi akademiyi Derzhavnoyi prykordonnoyi sluzhby Ukrayiny imeni Bohdana Khmelnytskoho, protokol vid 16 kvitnya 2015 roku № 5 (2015) [Strategy of development of the National Academy of the State Border Guard Service of Ukraine named after Bogdan Khmelnytsky for the period up to 2021]. Khmelnytskyy : Vyd-vo Nats. akad. Derzh. prykordon. sluzhby Ukrayiny im. B. Khmelnytskoho (in Ukrainian).

2. Bilyavets S. YA. (2017) Tendentsiyi profesiynoyi pidhotovky fakhivtsiv prykordonnykh vidomstv u providnykh krayinakh Yevropy v KHKH-KHKHI stolittyakh [Trends of professional training of specialists of border agencies in the leading European countries in the XX-XXI centuries]. Molodyy vchenyy, 7 (47), 257-262 (in Ukrainian).

3. Bloshchynskyi I. H. (2017) Peculiarities of professional training of the US Border Patrol Special Operations Group`s agents. Comparative Professional Pedagogy. 2017. Vol. 7. Issue 3. pp. 42-48 (in English).

4. Bloshchynskyi I. H. (2015) Peculiarities of US Border Guard Officer's Training at the Federal Law Enforcement Training Center Using Online Campus. Comparative Professional Pedagogy. 2015. Vol. 5. Issue 4. pp. 57-61 (in English).

5. Sychevskyy YU. O. (2017) Osoblyvosti pidhotovky maybutnikh ofitseriv mytnoprykordonnoyi sluzhby Spoluchenykh Shtativ Ameryky do zdiysnennya prykordonnoho kontrolyu [Features of the training of future officers of the United States Customs and Border Guard Service for the implementation of border control]. Zbirnyk naukovykh prats Natsionalnoyi akademiyi Derzhavnoyi prykordonnoyi sluzhby Ukrayiny. Seriya : Pedahohichni nauky, 4, 388-403 (in Ukrainian).

6. Ryndenko N. M. (2016) Tendentsiyi komunikatyvnoyi pidhotovky kursantiv navchalnykh zakladiv Prykordonnoyi varty Respubliky Polshcha [Trends of communicative training of cadets of educational institutions of the Border Guard of the Republic of Poland] avtoref. dys. ... kand. ped. nauk: 13.00.04 / Nats. akad. Derzh. prykordon. sluzhby Ukrayiny im. Bohdana Khmelnytskoho. Khmelnytskyy (in Ukrainian).

7. Balendr A. V. (2017) Struktura haluzevoyi ramky kvalifikatsiy dlya pidhotovky prykordonnykiv krayin Yevropeyskoho Soyuzu [Structure of the sectoral qualification framework for the preparation of border guards of the countries of the European Union]. Viyskova osvita, 1, 12-18. Available at: http://nbuv.gov.ua/UJRN/vios_2017_1_4 (in Ukrainian).

8. Balendr A. V. (2018) Unifikovana prohrama bazovoho rivnya dlya pidhotovky fakhivtsiv z okhorony kordonu krayin Yevropeyskoho Soyuzu [A unified basic level program for the training of border guards of the European Union countrie]. Pedahohichnyy dyskurs, №25, 17-21. Available at: https://doi.org/10.31475/ped.dys.2018.25.02 (in Ukrainian).

9. Common Core Curriculum for Border Guard Basic training in the European Union (CCC 2017). (2017). Warsaw, Poland: Rondo ONZ 1 (in English).

10. Osvitn $\square$ o-profesiyna prohrama pershoho rivnya vyshchoyi osvity za spetsialnistyu 252 «Bezpeka derzhavnoho kordonu» haluz znan 25 «Voyenni nauky, natsionalna bezpeka, bezpeka 
derzhavnoho kordonu» (2018) [Educational and professional program of the first level of higher education in the specialty 252 «Security of the state border» branch of knowledge 25 «Military sciences, national security, security of the state border»]. Khmelnytskyy : Vyd-vo Nats. akad. Derzh. prykordon. sluzhby Ukrayiny im. B. Khmelnytskoho (in Ukrainian).

\title{
РЕЗЮМЕ
}

Александр Лазоренко, кандидат психологических наук Национальная академия Государственной пограничной службы Украины имени Богдана Хмельницкого

\section{Сравнительный анализ образовательно-профессиональной программы подготовки будущих бакалавров безопасности государственной границы с унифицированной программой подготовки пограничников Европейского Союза}

В статье проведен сравнительный анализ образовательно-профессиональной программы подготовки будущих бакалавров безопасности государственной гранищь $c$ Унифищированной программой подготовки пограничников Европейского Союза. Доказано, что программы подготовки имеют как общие черты, так и отличительные признаки. Установлено, что частичное несоответствие рекомендациям Унифицированной программь обусловлено особенностью начионального законодательства относительно разграничения функиий государственных органов, которые осуществляют деятельность на государственной границе. По мнению автора, сочетание практического опыта обучения пограничников Украины и EC будет способствовать решению многих проблем, существующих в системе подготовки будущих бакалавров безопасности государственной границы.

Ключевые слова: сравнительный анализ; подготовка; будущие бакалавры безопасности государственной граниџь;; пограничники.

\section{SUMMARY} \\ Olexandr Lazorenko, \\ Candidate of Psychological Science \\ National Academy of the State Border Guard Service of Ukraine \\ the name of Bogdan Khmelnitsky
}

\section{Comparative analysis of educational and vocational training program for Ukrainian future bachelors of state border security with EU CCC for basic border guards training}

Introduction. The topicality of the article is determined by the need for further adaptation of military personnel training to the "Bologna" standards, taking into account the strategic course of Ukraine for integration into the EU and Euro-Atlantic structures, which prompts to seek new approaches to the training of military specialists, including future bachelors of state border security. A comparative analysis of the personnel training organization of the border authorities of the EU and Ukraine will help to bring the quality of training of future bachelors of state border security to the European and world standards.

Purpose. To perform comparative analysis of the structure and content of the educational and vocational training programs for Ukrainian future bachelors of state border security with European Union Common Core Curriculum for basic border guards training (EU CCC).

Methods. Scientific analysis of the research problem; generalization and systematization of theoretical data on of border guards' training; comparison, classification, induction and deduction.

Results. The educational and vocational training programs of Ukrainian border guards and the European Union have both common features and distinctive features. Common features of the 
programs: compliance with the requirements of the "Bologna" declaration; step training model; border guards receive a solid theoretical and practical training; substantially developed practical orientation in accordance with the tasks of the state border protection.

Results. Differences in some topics are due to differences in national legislation with the EU legislation on the distribution of the functions of state authorities that carry out their activities at the state border. Also, considering the complexity of the military-political situation in the east of our country, the training of Ukrainian border guards has paid more attention to the disciplines of the military-border area.

Originality. The comparative analysis of the educational and professional training programs of Ukrainian future bachelors of state border security with European Union Common Core Curriculum for basic border guards training promotes the combination of practical experience of training the border guards of Ukraine and the EU.

Conclusion. It was established that in the vast majority of the disciplines of educational and professional training programs of Ukrainian future bachelors of state border security in general correspond to the topics of European Union Common Core Curriculum for basic border guards training, that testifies to the integration of Ukraine's border guards training system into the European educational one. A perspective direction for further research is to compare competencies and learning outcomes of these educational and professional training programs, as well as the implementation of new ideas in the training of future bachelors of state border security.

Key words: comparative analysis; training; future bachelors of state border security; border guards. 